\title{
REKONSTRUKSI KESETARAAN DAN KEADILAN GENDER DALAM KONTEKS SOSIAL BUDAYA DAN AGAMA
}

\author{
Mufidah Ch \\ Dosen Fakultas Syari'ah, Ketua PSG UIN Malang \\ dan Kandidat Doktor IAIN Sunan Ampel Surabaya
}

\begin{abstract}
ABSTRAK
Gender study concerns with the effort to posit the women and men in equal position as a part of social system integratively. The aim of the effort is to eliminate gender equality which exists in society due to socio-cultural, political policies as well as religious doctrine interpretations factors. To realize this equal gender relation between men and women, gender analysis technique is used particularly in development process to assess the causes and the problems of unequal gender relation of both sexes. Thus, the result of analysis can be used as the considerations for women empowerment program to build up women's potentials that they can participate in development process together with men.
\end{abstract}

\section{A. Pendahuluan}

Studi tentang gender bukan hanya sekedar sebuah upaya memahami perempuan atau laki-laki secara terpisah, tetapi bagaimana menempatkan keduanya dalam konteks sistem sosial di mana keduanya menjadi bagian integral di dalamnya. Ketika perbedaan yang berakar dari kelas sosial ekonomi, perbedaan etnis, perbedaan ras dan warna kulit maupun perbedaan agama yang melahirkan masalah ketidakadilan sosial di masyarakat telah dapat diatasi seiring dengan lahirnya Deklarasi Umum Hak-hak Asasi Manusia (DUHAM) dan diakui oleh bangsa-bangsa di dunia, maka lain halnya dengan perbedaan jenis kelamin (gender) yang masih dianggap belum selesai, bukan hanya di negara terbelakang, dan negara berkembang, tetapi juga masih menjadi bagian perjuangan perempuan di negara maju.

Membangun kesetaraan dan keadilan gender sulit dilakukan secara cepat, karena masih mengalami kendala-kendala yang bersumber dari legitimasi konstruksi budaya, interpretasi agama, dan kebijakan politik. Upaya mewujudkan kesetaraan dan keadilan gender dalam seluruh lini kehidupan perlu dilakukan secara terus menerus dan bertahap, dimulai dari komunitas terkecil seperti dalam keluarga hingga secara makro melalui 
kebijakan formal negara, maupun kebijakan informal tokoh masyarakat dan tokoh agama terkait dengan kendala-kendala struktural maupun kultural. Kesetaraan dan keadilan gender akan terwujud jika secara personal masing-masing individu telah memiliki sensitifitas gender, dan secara kelembagaan telah mengimplementasikan kebijakan reponsif gender.

\section{B. Definisi Gender}

Sejak dua dasawarsa terakhir, konsep gender memasuki bahasan dalam berbagai seminar, diskusi maupun tulisan di seputar perubahan sosial dan pembangunan dunia ketiga. Istilah gender lazim dipergunakan dikantor Menteri Negara Pemberdayaan Perempuan sejak beberapa tahun lalu. Sekalipun demikian kebanyakan orang masih belum memahami gender dengan pemahaman yang benar. Sebab, dalam kamus bahasa Indonesia antara gender dengan seks belum mempunyai perbedaan pengertian yang transparan. Kata "gender" banyak dipergunakan dengan kata yang lain, seperti ketidakadilan, kesetaraan dan sebagainya, keduanya sulit untuk diberi pengertian secara terpisah. Nasaruddin Umar ${ }^{1}$ memberikan pengertian gender sebagai suatu konsep yang digunakan untuk mengidentifikasi perbedaan laki-laki dan perempuan dilihat dari segi sosial budaya. Gender dalam arti tersebut mengidentifikasikan laki-laki dan perempuan dari sudut nonbiologis.

Agar memudahkan dalam memberikan pegertian gender tersebut, pengertian gender dibedakan dengan pengertian seks (Jenis Kelamin). Pengertian jenis kelamin merupakan penafsiran atau pembagian dua jenis kelamin manusia yang ditentukan secara biologis yang melekat pada jenis kelamin tertentu, dengan (alat) tanda-tanda tertentu pula. Alat-alat tersebut selalu melekat pada manusia selamanya, tidak dapat dipertukarkan, bersifat permanen, dan dapat dikenali semenjak manusia lahir. Itulah yang disebut dengan ketentuan Tuhan atau kodrat. Dari sini melahirkan istilah identitas jenis kelamin.

Gender melekat pada kaum laki-laki maupun perempuan, dikonstruksi secara sosial maupun kultural. Misalnya perempuan itu dikenal lemah lembut, cantik, emosional dan keibuan. Sementara laki-laki dianggap kuat, rasional, jantan perkasa. Ciri dari sifat itu merupakan sifat-sifat yang dimiliki oleh kedua belah fihak. Artinya ada laki-laki yang emosional, lemah lembut, dan keibuan. Sementara itu juga, ada perempuan yang kuat,

\footnotetext{
${ }^{1}$ Nasaruddin Umar, Argumen Kesetaraan Gender (Jakarta: PARAMADINA, 1999) hal. 35
} 
rasional dan perkasa. Perubahan ciri dari sifat-sifat itu dapat terjadi dari waktu ke waktu dan dari tempat ke tempat yang lain. ${ }^{2}$ Dari sini melahirkan istilah identitas gender.

Perbedaan gender (gender differences) antara manusia laki-laki dan perempuan terjadi melalui proses yang panjang. Pembentukan gender ditentukan oleh sejumlah faktor yang ikut membentuk, kemudian disosialisasikan, diperkuat, bahkan di konstruk melalui sosial atau kultural, dilanggengkan oleh interpretasi agama dan mitos-mitos, seolah-olah telah menjadi keyakinan. Proses selanjutnya perbedaan gender dianggap suatu ketentuan Tuhan yang tidak dapat diubah sehingga perbedaan tersebut dianggap kodrati. Untuk memahami perbedaan antara seks dan gender dapat dilihat pada tabel berikut ini:

\begin{tabular}{|c|c|c|c|c|}
\hline IDENTIFIKASI & LAKI-LAKI & PEREMPUAN & SIFAT & KATEGORI \\
\hline Ciri biologis & $\begin{array}{l}\text { Penis } \\
\text { Jakun } \\
\text { Spirma }\end{array}$ & $\begin{array}{l}\text { Vagina } \\
\text { Payudara (ASI) } \\
\text { Ovum } \\
\text { Rahim } \\
\text { Haid } \\
\text { Hamil melahirkan } \\
\text { Menyusui }\end{array}$ & $\begin{array}{l}\text { Tetap, tidak dapat } \\
\text { dipertukarkan. } \\
\text { Kodrati } \\
\text { Pemberian Tuhan. }\end{array}$ & $\begin{array}{l}\text { JENIS } \\
\text { KELAMIN/ } \\
\text { SEKS }\end{array}$ \\
\hline Sifat/karakter & $\begin{array}{l}\text { Rasional } \\
\text { Kuat } \\
\text { Cerdas } \\
\text { Pemberani } \\
\text { Superior } \\
\text { Maskulin }\end{array}$ & $\begin{array}{l}\text { Emosional } \\
\text { Lemah } \\
\text { Bodoh } \\
\text { Penakut } \\
\text { Inferior } \\
\text { Feminin }\end{array}$ & $\begin{array}{l}\text { Ditentukan oleh } \\
\text { masyarakat. } \\
\text { Disosialisasikan. } \\
\text { Dimiliki oleh laki- } \\
\text { laki dan perempuan. } \\
\text { Dapat berubah sesuai } \\
\text { kebutuhan }\end{array}$ & GENDER \\
\hline Peran & $\begin{array}{l}\text { Kepala keluarga } \\
\text { Pencari nafkah } \\
\text { Pemimpin } \\
\text { Direktur } \\
\text { Kepala kantor } \\
\text { Pilot } \\
\text { Dokter } \\
\text { Sopir } \\
\text { Mandor }\end{array}$ & $\begin{array}{l}\text { Ibu rumah tangga } \\
\text { Manajemen rumah } \\
\text { tangga } \\
\text { Dipimpin } \\
\text { Sekretaris } \\
\text { Pramugari } \\
\text { Perawat } \\
\text { Pembantu rumah } \\
\text { tangga } \\
\text { Buruh }\end{array}$ & $\begin{array}{l}\text { Konstruk masyarakat } \\
\text { Dapat berubah sesuai } \\
\text { kebutuhan }\end{array}$ & GENDER \\
\hline
\end{tabular}

Dengan demikian dapat disimpulkan bahwa:

\footnotetext{
${ }^{2}$ Mansour Faqih, Gender dan Transformasi sosial (Yogyakarta: Pustaka Pelajar, 1997) hal. 8-9
} 
Jenis Kelamin adalah : Perbedaan antara laki-laki dan perempuan yang ditentukan oleh perbedaan biologis yang melekat pada keduanya. (Jenis Kelamin : tafsir sosial atas perbedaan biologis laki-laki dan perempuan). Gender adalah : Perbedaan peran, fungsi dan tanggung jawab antara perempuan dan laki-laki yang dihasilkan dari konstruksi sosial budaya dan dapat berubah sesui dengan perkembangan zaman. (Gender: Jenis kelamin Sosial)

Perbedaan jenis kelamin sering dipergunakan masyarakat untuk mengkonstruk pembagian peran (kerja) laki-laki dan perempuan atas dasar perbedaan tersebut. Pada pembagian kerja gender atas jenis kelamin di mana laki-laki dan perempuan melakukan jenis pekerjaan yang berbeda dan pembagian ini dipertahankan serta dilakukan secara terus menerus. Pembagian kerja berdasar gender tidak menjadi masalah selama masing-masing pihak tidak merugikan atau dirugikan.

Namun dalam realitas kehidupan telah terjadi perbedaan peran sosial laki-laki dan perempuan di atas melahirkan perbedaan status sosial di masyarakat, di mana laki-laki lebih diunggulkan dari perempuan melalui konstruksi sosial. Untuk lebih jelas dapat dibandingkan pada peran sosial, sifat kegiatan dan jenis pekerjaan sebagaimana tabel di bawah ini:

\begin{tabular}{|c|c|c|}
\hline & LAKI-LAKI & PEREMPUAN \\
\hline Peran Sosial & $\begin{array}{l}\text { Organisasi politik } \\
\text { Pencari nafkah utama } \\
\text { Pelindung keluarga } \\
\text { Pengambil keputusan/kebijakan }\end{array}$ & $\begin{array}{l}\text { Komunitas setempat (arisan, PKK, } \\
\text { Keluarga, Pengajian) } \\
\text { Pencari nafkah tambahan/ pengganti } \\
\text { Perawat, pendidik anak }\end{array}$ \\
\hline Sifat Kegiatan & $\begin{array}{l}\text { Publik } \\
\text { Produktif } \\
\text { Berupa lebih besar } \\
\text { Membutuhkan keterampilan terlatih/ } \\
\text { terdidik } \\
\text { Membutuhkan manajemen modern } \\
\text { Melibatkan teknologi } \\
\text { Melibatkan aspek kekuasaan lebih } \\
\text { besar } \\
\text { Sektor formal }\end{array}$ & $\begin{array}{l}\text { Domestik } \\
\text { Bersifat produktif } \\
\text { Tidak berupah/ rendah } \\
\text { Dianggap alamiah } \\
\text { Manajemen sederhana } \\
\text { Penggunaan teknologi terbatas } \\
\text { Penerimaan kekuasaan } \\
\text { Sektor informal }\end{array}$ \\
\hline Pekerjaan & $\begin{array}{l}\text { Sopir } \\
\text { Pengusaha } \\
\text { Satpam } \\
\text { Mandor }\end{array}$ & $\begin{array}{l}\text { Ibu rumah tangga } \\
\text { Sekretaris } \\
\text { Pedagang kecil } \\
\text { Pramugari }\end{array}$ \\
\hline
\end{tabular}




\begin{tabular}{|l|l|l|}
\hline & Dosen & Pekerja rumah tangga \\
Manager & Buruh \\
Dokter & Baby sitter \\
Teknisi mekanik & Guru TK \\
Pilot & Publik relation \\
Atlet & Bidan/ Perawat \\
Polisi & Dokter anak \\
Direktur & Resepsionis \\
\hline
\end{tabular}

Modul Pengarusutamaan Gender di Madrasah, PSW UIN Yogyakarta, 2005

\section{Ragam Pemaknaan Gender}

\section{Gender sebagai istilah asing dengan makna tertentu}

Perbedaan manusia berdasar jenis kelamin (sex) dikenal sebagai sexual differentiation, pembedaan seksual. Sedang "gender" sebagai istilah adalah hasil atau akibat dari pembedaan atas dasar jenis kelamin tersebut. Pada konteks ini sering terjadi perbedaan persepsi karena gender berasal dari bahasa asing yang sulit dicari padan katanya. Berbeda dengan kata "demokrasi", "politik", ekonomi dan sebagainya mudah untuk diterima karena tidak menimbulkan dampak pada terusiknya status dan peran lakilaki yang sejak semula telah diunggulkan oleh konstruk budaya. Sehingga tidak heran ketika perempuan sendiri sering menolak "gender" karena dianggap melampaui tatanan kehidupan dalam masyarakat.

\section{Gender sebagai fenomena sosial-budaya}

Gender sebagai fenomena sosial berarti sebab akibat atau implikasi sosial (kemasyarakatan) yang muncul dalam masyarakat karena pembedaan yang didasarkan pada perbedaan jenis kelamin, yaitu laki-laki dan perempuan. Akibat - akibat sosial ini bisa berupa pembagian kerja, sistem penggajian, proses sosialisasi dan sebagainya. Gender sebagai fenomena budaya berarti akibat-akibat atau implikasi dalam budaya (yaitu pada pola dan isi pemikiran) yang muncul dalam masyarakat karena adanya klasifikasi dualistis yang didasarkan pada perbedaan antara laki dan perempuan.

\section{Gender sebagai kesadaran sosial}

Gender juga perlu dipahami sebagai kesadaran sosial. Setiap orang yang mengetahui ada perbedaan antara laki-laki dan perempuan tidak selalu menyadari bahwa hal itu merupakan sesuatu yang bersifat sosial maupun kultural. Gender sebagai kesadaran 
sosial adalah kesadaran di kalangan warga masyarakat bahwa hal-hal yang berasal atau diturunkan dari pembedaan antara laki-laki dan perempuan adalah hal-hal yang bersifat sosial budaya atau merupakan sesuatu yang dibentuk oleh tatanan. Disini warga masyarakat mulai menyadari bahwa pembagian kerja antara laki-laki dan perempuan misalnya bukanlah sesuatu yang alami, yang telah "ditakdirkan", yang diterima begitu saja, tetapi merupakan produk sejarah adaptasi atau hubungan masyarakat dengan lingkungan.

\section{Gender sebagai persoalan sosial budaya}

Pembedaan laki-laki dan perempuan bukan merupakan masalah bagi kebanyakan orang, tetapi pembedaan ini menjadi masalah ketika menghasilkan ketidaksetaraan, dimana laki-laki memperoleh dan menikmati kedudukan yang lebih baik dan menguntungkan daripada perempuan. Jadi yang menjadi persoalan bukan hanya perbedaan laki-laki dan perempuan. Lebih jauh, pembedaan laki-laki dan perempuan telah menjadi landasan ketidaksetaraan tersebut, karena masyarakat memandang perempuan lebih rendah dari pada laki-laki. Gender sebagai persoalan sosial-budaya adalah ketidaksetaraan gender yang menghasilkan pelbagai bentuk ketidakadilan dan penindasan berdasar jenis kelamin dan perempuan merupakan pihak yang lebih rentan sebagai korban. Semuanya ini merupakan kenyataan yang dibentuk oleh tatanan sosial, budaya dan sejarah, karena itu sebenarnya dapat dan perlu dirubah. Perubahan ini tentu saja tidak mudah, karena untuk dapat melakukannya diperlukan analisis serta penarikan kesimpulan yang tepat. Disinilah gender sebagai alat analisis menjadi penting peranannya.

\section{Gender sebagai sebuah konsep untuk analisis}

Dalam ilmu sosial, defisini gender tidak lepas dari asumsi-asumsi dasar yang ada pada sebuah paradigma, dimana konsep analisis merupakan salah satu komponennya. Asumsi-asumsi dasar itu umumnya, merupakan pandangan-pandangan filosofis dan juga ideologis. Yang menjadi persoalan, definisi mana yang akan digunakan? misalnya, konsep gender didefinisikan sebagai hasil atau akibat dari pembedaan atas dasar jenis kelamin atau yang lainnya, sesuai dengan paradigma yang digunakan dalam penelitian. Gender sebagai konsep untuk analisis merupakan gender yang digunakan oleh seorang ilmuwan dalam mempelajari gender sebagai fenomena sosial budaya.

\section{Gender sebagai sebuah perspektif untuk memandang suatu realitas gerakan}

Dalam term ini, gender menjadi sebuah paradigma atau kerangka teori lengkap dengan asumsi dasar, model, dan konsep-konsepnya. Seorang peneliti menggunakan 
ideologi gender untuk mengungkap pembagian peran atas dasar jenis kelamin serta implikasi-implikasi sosial budayanya, termasuk ketidakadilan yang ditimbulkannya. Penelitian yang dilakukan dengan perspektif gender akan menonjolkan aspek kesetaraan dan kadang-kadang menjadi bias perempuan, karena kenyataan menuntut demikian. Misalnva apakah kategori-kategori dalam kehidupan dimasyarakat menimbulkan ketidakadilan gender?, bagian-bagian mana saja?, dan pihak mana yang lebih diuntungkan? Dalam hal ini, peneliti dituntut untuk memiliki sensitivitas gender yang baik.

\section{Ketimpangan Gender dan Konstruksi Sosial Budaya}

Setelah diketahui perbedaan pengertian seks dan pengertian gender maka muncul satu pertanyaan, mengapa perbedaan seks menyebabkan perbedaan gender? Telaah lebih lanjut dalam persoalan ketidakadilan gender mengacu pada konstruksi sosial yang dibangun di atas budaya patriarki yang tertanam kuat dalam masyarakat secara luas. Perbedaan gender selanjutnya melahirkan peran gender yang sesungguhnya tidak menjadikan masalah jika seandainya tidak terjadi ketimpangan yang berakhir pada ketidakadilan gender.

Peran gender (gender role) tersebut kemudian diterima sebagai ketentuan sosial, bahkan oleh masyarakat diyakini sebagai kodrat. Ketimpangan sosial yang bersumber dari perbedaan gender itu sangat merugikan posisi perempuan dalam berbagai komunitas sosialnya. Akibatnya ketidakadilan gender tersebut antara lain : 1) marginalisasi perempuan, 2) penempatan perempuan pada subordinat, 3) stereotype perempuan, 4) kekerasan (violence) terhadap perempuan, dan 5) beban kerja tidak proposional. ${ }^{3}$

\section{Stereotype Perempuan}

Stereotype adalah pelabelan terhadap kelompok suku bangsa tertentu yang selalu berkonotasi negatif sehingga sering merugikan dan timbul ketidakadilan. Pelabelan atau penandaan yang terkait dengan perbedaan dengan jenis kelamin tertentu (perempuan) akan menimbulkan kesan yang negatif yang merupakan keharusan disandang oleh perempuan.

\section{Sub Ordinasi Perempuan}

Sebuah pandangan yang tidak adil terhadap perempuan dengan anggapan dasar bahwa perempuan itu irasional, emosional, lemah, dan lain-lainnya, menyebabkan penempatan

\footnotetext{
${ }^{3}$ Faqih, Gender............, hal.12
} 
perempuan dalam peran-peran yang dianggap kurang penting. Potensi perempuan sering dinilai tidak fair oleh sebagian besar masyarakat akibat sulitnya mereka menembus posisi-posisi strategis dalam komunitasnya, terutama yang berhubungan dengan peran pengambilan keputusan.

\section{Marginalisasi Perempuan}

Proses marginalisasi terhadap pcrempuan dapat terjadi karena program industrialisasi. Program tersebut menyebabkan terpinggirkannya peran perempuan. Semula, mereka menjadi salah satu sumber daya manusia, akibat diterapkannya teknologi canggih, misalnya mengganti tenaga bagian linting rokok, pengepakan dan proses produksi dalam suatu perusahaan dengan mesin-mesin yang lebih praktis dan ekonomis, kemudian alat-alat produksi tersebut hanya diperankan oleh laki-laki. Selain itu, mesinmesin potong padi menggantikan pekerjaan ani-ani yang semula diperankan oleh perempuan, kemudian diganti dengan sabit karena jenis padi yang ditanam harus menggunakan sabit, di mana sabit menjadi alat kerja laki-laki, maka mengetam padi berubah menjadi peran laki-laki sehingga perempuan kehilangan pekerjaan. Marginalisasi itu merupakan proses pemiskinan perempuan terutama pada masyarakat lapis bawah. Demikian pula marginalisasi dalam lingkungan keluarga biasa terjadi di tengah masyarakat. Misalnya, anak laki-laki memperoleh fasilitas, kesempatan dan hak-hak yang lebih dari pada anak perempuan.

\section{Beban Kerja yang Tidak Proposional}

Budaya patriarki beranggapan bahwa perempuan tidak punya hak untuk menjadi pemimpin rumah tangga. Sebaliknya, ia berhak untuk diatur. Pekerjaan domestik yang dibebankan kepadanya menjadi identik dengan dirinya sehingga posisi perempuan sarat dengan pekerjaan yang beragam macamnya, dalam waktu yang tidak terbatas dan dengan beban yang berlipat, misalnya: memasak, mencuci, menyetrika, menjaga kebersihan kerapian rumah, membimbing belajar anak-anak dan sebagainya. Pekerjaan domestik yang berat tersebut dilakukan bersama-sama dengan fungsi reproduksi, haid, hamil, melahirkan, dan menyusui. Sementara laki-laki dengan peran publiknya menurut kebiasaan masyarakat (konstruk sosial) tidak bersentuhan dengan beban kerja domestik-reproduktif, karena pekerjaan ini dipandang hanya layak dikerjakan oleh perempuan. Pembagian kerja secara dikotomi publik-domestik, di mana pekerjaan di sektor publik mendapat imbalan secara ekonomis, sedangkan sektor publik tidak mendapatkan. Hal itu menyebabkan hasil kerja perempuan yang terlalu berat dianggap 
pekerjaan rendah. Realitas tersebut memperkuat ketidakadilan gender yang telah melekat dalam kultur masyarakat.

\section{Kekerasan (Violence) 'I'erhadap Perempuan}

Salah satu bentuk ketidakadilan gender adalah kekerasan terhadap perempuan baik yang berbentuk kekerasan fisik, psikis, ekonomi maupun seksual. Kekerasan itu timbul akibat beberapa faktor di atas, termasuk anggapan bahwa laki-laki pemegang supermasi dan dominasi terhadap berbagai sektor kehidupan. Fenomena itu oleh masyarakat dianggap sebagai sesuatu yang sangat wajar jika perempuan menerima perlakuan tersebut. Kekerasan fisik misalnya pemukulan, penganiayaan dan pembunuhan. Kekerasan psikis seperti penghinaan, sikap, ungkapan melalui verbal atau perkataan yang dapat menyebabkan sakit hati dan hal-hal yang dapat menimbulkan rasa tidak nyaman. Kekerasan seksual seperti pelecehan seksual, pencabulan, pemerkosaan, eksploitasi seksual pada dunia kerja, pemaksaan penggunaan alat kontrasepsi dan pengrusakan organ reproduksi.

\section{E. Kesetaran dan Keadilan Gender}

Untuk mewujudkan relasi gender yang berkeadilan sedapat mungkin menghilangkan kesenjangan hubungan dan pembagian kerja antara laki-laki dan perempuan dalam berbagai bidang kehidupan dengan memperhatikan kodrat, harkat, dan martabatnya. Lebih lanjut, diketahui pula latar belakang kondisi dan masalah yang menjadi penyebabnya dengan menggunakan teknik analisis gender.

Teknik analisis gender dikembangkan di Indonesia dimaksudkan untuk mengetahui kesenjangan serta ketimpangan gender dalam proses pembangunan. Dengan mengetahui kesenjangan dan ketimpangan serta latar belakang munculnya dapat dijadikan dasar arah pemberdayaan perempuan agar kesetaraan gender terwujud dalam kehidupan sehari-hari. Dengan cara pandang yang demikian, pemberdayaan perempuan tidak dilandasi oleh sikap atau keinginan untuk menciptakan persaingan yang tidak sehat, tetapi kompetisi yang berkeadilan yang diharapkan karena pada hakekatnya laki-laki dan perempuan potensial untuk sama-sama berusaha dan berprestasi baik mandiri maupun bekerja sama lintas gender.

Kesetaran gender (gender equity) adalah suatu proses yang ditempuh untuk menghantarkan laki-laki dan perempuan secara dinamis untuk memperoleh akses, partisipasi, kontrol, dan manfaat dalam aktifitas kehidupan baik dalam keluarga, 
masyarakat maupun berbangsa dan bernegara. Untuk itu diperlukan upaya untuk memperbaiki kondisi secara kualitas maupun kemampuan bagi kelompok yang tertinggal baik perempuan maupun laki-laki melalui affirmative action.

Keadilan gender (gender equality) adalah suatu kondisi yang setara, selaras, seimbang, serasi, tanpa diskriminasi. Suatu kondisi yang sama antara laki-laki dan perempuan dalam mencapai hak-hak dasar dalam lingkup keluarga, masyarakat, negara dan dunia internasional. Kesamaan pemenuhan hak-hak dasar akan meningkatkan kualitas dan martabat kemanusiaan laki-laki Perempuan secara adil.

Affirmative action adalah suatu tindakan khusus yang dilakukan untuk mendorong upaya kesetaraan gender menuju keadilan gender dengan lebih memperhatikan jenis kelamin tertentu yang sedang mengalami ketertinggalan dan ketidakadilan melalui jalur struktural seperti menetapkan Undang-undang, Peraturan Pemerintah, Instruksi Presiden, Peraturan Daerah, Anggaran Dasar/ Anggaran Rumah Tangga Organisasi atau policy dari pengambil kebijakan atau sejenisnya. Dalam hal ini negara berperan dalam upaya terwujudnya keadilan gender melalui tindakan affirmative action ${ }^{4}$. Misalnya memberikan cuti haid, hamil, melahirkan untuk melaksanakan peran reproduksi perempuan sebagai amanat Tuhan yang harus dihormati oleh setiap manusia. Penyediaan penitipan anak agar ibu yang bekerja dapat memberikan ASI pada jam-jam tertentu. Menetapkan kuota bagi perempuan dalam partisipasi politik, memberikan beasiswa pada anak perempuan atau laki-laki putus sekolah karena membantu bekerja mencari nafkah keluarga.

Affirmative action juga ditempuh melalui jalur kultural, misalnya melakukan perubahan pola pikir yang dimulai dari kajian akademis dengan memperhatikan keperpihakan terhadap fihak jenis kelamin tertentu yang sedang mengalami ketertingalan dan diskriminasi dengan menggunakan analisis gender. Hasil kajian tersebut kemudian diimplementasikan dalam kehidupan agar dapat merubah persepsi dan perilaku masyarakat menuju keadilan gender.

Kesetaraan yang berkeadilan gender adalah kondisi yang dinamis, dimana laki-laki dan perempuan sama-sama memiliki hak, kewajiban, peranan, dan kesempatan yang dilandasi oleh saling menghormati dan menghargai serta membantu di berbagai sektor. Untuk mengetahui apakah laki-laki dan perempuan telah setara dan berkeadilan, dapat dilihat pada :

1. Seberapa besar akses dan partisipasi atau keterlibatan perempuan terhadap peran-peran sosial dalam kehidupan baik dalam keluarga masyarakat, dan dalam pembangunan.

\footnotetext{
${ }^{4}$ Peggy Antrobus, The Global women Movement (Bangladesh: The university Press, 2004) hal.150
} 
2. Seberapa besar kontrol serta penguasaan perempuan dalam berbagai sumber daya manusia maupun sumber daya alam dan peran pengambilan keputusan dan lain sebagainya.

3. Seberapa besar manfaat yang diperoleh perempuan dari hasil pelaksanaan berbagai kegiatan baik sebagai pelaku maupun sebagai pemanfaat dan penikmat hasilnya.

Menyadari pentingnya mewujudkan keadilan gender dewasa ini fokus penanganannya tidak hanya melibatkan perempuan, tetapi lebih ditujukan kepada keduanya (laki-laki dan perempuan) yang kemudian dikenal dengan istilah "relasi gender". Dari relasi yang berkeadilan gender akan muncul peran-peran "komunitas" antara keduanya yang dapat dilakukan sepanjang tidak melampaui kodrat keduanya, baik peran domestik maupun peran publik, misalnya merawat dan mendidik anak, mengerjakan pekerjaan rumah tangga, mencari nafkah, pengambilan keputusan, dan sebagainya.

Untuk menuju kesetaraan dan keadilan gender diperlukan sosialisasi di tingkat personal agar memiliki sensitivitas gender, yakni suatu sikap dan perilaku yang tanggap dan peka terhadap adanya kesenjangan gender dengan memberi kesempatan dan peluang yang sama untuk mencapai kemajuan dalam berbagai bidang kehidupan. Sosialisasi pada level institusional diperlukan untuk mewujudkan responsibilitas gender melalui produk hukum dan kebijakan yang ditetapkan berdasarkan analisis gender, misalnya menggunakan strategi Pengarusutamaan Gender (PUG) dengan teknik Gender Analysis Pathway (GAP)

Pengarusutamaan gender adalah salah satu strategi untuk memasukkan isu dan pengalaman perempuan dan laki-laki ke dalam suatu dimensi yang integral dalam rancangan, pelaksanaan, pemantauan, dan evaluasi kebijakan dan program dalam setiap bidang agar perempuan dan laki-laki mendapat manfaat yang sama. PUG merupakan pendekatan untuk mengembangkan kebijakan pembangunan yang mengintegrasikan pengalaman dan masalah perempuan dan laki-laki ke dalam proses perencanaan, pelaksanaan, pemantauan dan evaluasi kebijakan dan program pembangunan.

PUG bertujuan terselenggaranya perencanaan, penyusunan, pelaksanaan, pemantauan, dan evaluasi atas kebijakan dan program dalam pembangunan nasional yang berperspektif gender dalam rangka mewujudkan kesetaraan dan keadilan gender dalam kehidupan keluarga, bermasyarakat, berbangsa dan bernegara.

Sedangkan GAP merupakan salah satu alat analisis gender yang dapat membantu para perencana dalam melakukan pengarusutamaan gender dalam perencanaan kebijakan atau program pembangunan. Metode ini dimaksudkan untuk mengetahui kesenjangan gender dengan melihat aspek akses, partisipasi, kontrol dan manfaat program-program 
pembangunan. Dan berguna pula untuk mengidentifikasi kesenjangan gender dan permasalahan gender serta sekaligus menyusun rencana/kebijakan/program/proyek/ kegiatan yang ditujukan untuk memperkecil atau menghapus kesenjangan gender tersebut.

Sosialisasi gender melalui jalur struktural yang dipandang lebih efektif adalah melalui pendidikan, yakni dengan menintegrasikan ke dalam manajemen pendidikan responsif gender, pembelajaran inklusif gender dan didukung pula oleh kebijakan pendidikan yang responsif gender. Pembelajaran inklusif gender adalah pembelajaran dengan mengintegrasikan gender ke dalam materi/bahan ajar yang berkesetaraan dan keadilan gender dengan menggunakan metode pembelajaran yang menghindari terjadinya diskriminasi gender. Demikian pula dengan melalui strategi yang sama juga berlaku pada materi dan metode penyampaian pesan-pesan keagamaan inklusif gender yang dilakukan oleh pemuka agama. Hal ini penting artinya dalam mewujudkan kesetaraan dan keadilan gender melalui jalur kultural yang dinilai lambat tapi terintegrasi langsung dalam kehidupan sehari-hari di masyarakat.

\section{F. Hambatan konstruksi kesetaraan gender.}

Masalah sulitnya membangun kesetaraan dan keadilan gender baik melalui jalur struktural maupun kultural tidak lepas dari lima hal tersebut di atas (stereotype, subordinasi, marjinalisasi, beban berlipat dan kekerasan terhadap perempuan), yang terus menerus berlangsung karena terdapat legitimasi yang menjadi hambatan dalam membangun kesetaraan dan keadilan gender tersebut. Sumber legitimasi dimaksud adalah: (1). Legitimasi sosial budaya, (2). Legitimasi interpretasi agama, dan (3). Peraturan perundang-undangan dan kebijakan dan program pembangunan yang masih bias gender.

\section{Legitimasi budaya dalam konstruksi gender.}

Dalam membahas status dan peran laki-laki dan perempuan, masyarakat mengenal dua bentuk budaya yaitu patriarkhi atau patrilineal dan matriarkhi atau matrilineal. Pada budaya patriarkhi misalnya budaya Batak, lebih mengunggulkan laki-laki dari pada perempuan, sedangkan pada budaya matriarkhi misalnya budaya Minangkabau lebih mengunggulkan perempuan. Kedua budaya tersebut sama-sama tidak menguntungkan kedua belah fihak karena salah satu memiliki status, peran, kekuasaan, wewenang dan hakhak yang lebih dominan dari jenis kelamin lainnya.

Kondisi demikian ini berdampak pada relasi yang tidak setara, dan rentan terjadinya ketidakadilan sosial berbasis gender di masyarakat, dan jika ditinjau dari analisis gender 
mencerminkan adanya kesenjangan antara laki-laki dan perempuan. Ungkapan yang menjadi sebuah keyakinan atau mitos misalnya, istri itu swargo nunut neraka katut, konco wingking, dan sejumlah mitos yang dikaitkan dengan peran reproduksi perempuan yang bersifat kodrati, misalnya menstrual taboo masih ada di masyarakat.

Demikian pula praktek ritus-ritus di masyarakat, upacara-upacara keagamaan yang didominasi laki-laki karena status perempuan dalam agama dan kepercayaan dipandang tidak setara dengan laki-laki. Hal ini turut mendukung ketidaksetaraan antara laki-laki dan perempuan, yang kemudian menjadi ideologi yang sulit untuk dirubah. Masuknya gender ke dalam masyarakat dengan budaya demikian ini mengalami persoalan tersendiri, karena dianggap menghancurkan tatanan kehidupan yang telah mapan.

Realitas kehidupan di masyarakat selalu mengalami perubahan seiring dengan kemajuan ilmu pengetahuan dan teknologi. Namun norma-norma yang berlaku di masyarakat berkembang lambat, bahkan stagnan, artinya masyarakat mengalami perubahan perilaku yang berdampak pada ketimpangan gender di masyarakat seperti kekerasan, peran pencari nafkah, perubahan status karena akses pendidikan telah terbuka untuk perempuan, tetapi norma yang menyertai perubahan tersebut kurang adaptatif.

Fenomena demikian ini nampak dalam kehidupan, misalnya perempuan pencari nafkah utama dalam keluarga masih berstatus sebagai pembantu suami. TKW yang bekerja di luar negeri telah menjadi realitas jika mengalami masalah, norma berbicara bahwa kesalahan pada perempuan itu sendiri yang menyalahi fungsi utamanya sebagai ibu rumah tangga di ranah domestik. Sama halnya dengan perubahan status dan peran laki-laki dan perempuan di masyarakat, gender seharusnya tidak hanya dipandang sebagai fenomena sosial dan kesadaran sosial, tetapi telah memasuki ranah problem sosial dan juga alat analisis untuk merumuskan kembali norma-norma yang berkembang di masyarakat agar laki-laki dan perempuan memperoleh keadilan dalam kehidupan di masyarakat.

Perubahan norma yang diawali dengan perubahan persepsi individu maupun kolektif tidak selamanya berjalan maju dan mulus tanpa hambatan. Untuk membangun kesetaraan dan keadilan gender ini mengalami fluktuasi sejalan dengan kondisi sosial, politik, dan ekonomi yang sedang berlangsung. Untuk itu gender harus terus menerus disosialisasikan dalam semua kondisi, di manapun, oleh dan kepada siapapun, dan kapanpun. Bagaimana budaya patriarkhi dapat menimbulkan dampak ketimpangan gender dan apa upaya yang harus dilakukan untuk menuju kesetaraan gender, dapat diperhatikan bagan sebagai berikut: 


\section{Legitimasi interpretasi agama dalam konstruksi gender.}

Agama hadir tidak hanya untuk membawa misi kedamaian, tetapi juga membebaskan manusia dari belenggu ketertindasan, ketidakadilan dan keterbelakangan. Setiap pembawa agama (nabi dan rasul) berperan sebagai pengemban amanat Tuhan untuk tugas mulia tersebut tanpa memandang perbedaan jenis kelamin. Secara garis besar, ideal moral setiap agama adalah sama, seperti dalam memandang nilai-nilai kemanusiaan, keadilan, demokrasi, pluralitas dan kesetaraan. Namun dalam beberapa ayat yang termuat secara eksplisit mengarah pada bias gender, seolah-olah mengunggulkan jenis kelamin tertentu.

Dalam memahami teks suci tersebut secara sepintas dan tidak mendalam menyebabkan terjadi distorsi penafsiran, bahkan tereduksi sedemikian rupa, seolah-olah agama melakukan diskriminasi terhadap jenis kelamin tertentu. Turunnya teks suci, biasanya tidak steril dari berbagai persoalan yang mengitarinya, sedang terjadi apa, kepada siapa teks tersebut ditujukan, bagaimana kondisi masyarakat saat teks itu turun, metode apa yang dipergunakan untuk mendekatinya, siapa yang melakukan interpretasi, dan adakah intervensi penguasa yang turut membentuk. Pertanyaan tersebut membutuhkan jawaban yang konprehensip karena untuk memahami gender dikaitkan dengan agama tidak mudah diterima di masyarakat.

Akan tetapi seiring dengan perkembangan dan perubahan zaman, tantangan dan tuntutan realitaspun berubah. Sebagai konsekwensinya, penafsiran terhadap teks juga berubah. Metode yang dipakai bukan hanya tahlili yang menganalisis teks secara kronologis dan memaparkan berbagai aspek yang terkandung dalam teks sesuai dengan urutannya dalam mushaf, melainkan menggunakan metode maudhu'i yang menetapkan tema tertentu dengan menghimpun seluruh atau sebagian ayat-ayat dari beberapa surat, mencari relevansi diantara ayat untuk mengambil konklusi umum menurut pandangan alQur'an. Kendatipun demikian, keduanya hanya berada dalam taraf melihat dan memperhatikan apa yang dikatakan al-Qur'an, bukan bagaimana problematika realitas itu ada dan menuntut solusi.

Selain hal diatas, pada umumnya umat beragama, terutama di kalangan masyarakat awam dalam beragama, juga ingin menerima agama secara praktis dan instan, tanpa susah payah melakukan penelitian secara ilmiah. Dengan alasan bahwa agama dipahami untuk dilaksanakan dalam kehidupan. Dalam konteks ini figur pemuka agama menjadi sentral, pesan-pesan keagamaan yang disampaikan mendorong umat untuk taken for granted, statis dan fanatis buta. Hal ini tidak menjadi masalah jika figur pemuka agama telah memiliki 
sensitifitas gender, lain halnya jika mereka masih memahami teks suci secara bias gender, dapat mendukung terjadinya diskriminasi gender.

Realitas ketidakadilan sosial di masyarakat, termasuk di dalamnya ketidakadilan gender terabaikan karena norma yang dibangun atas nama tafsir agama tidak dapat dipertemukan dengan realitas umat beragama. Bagi yang mempertahankan teks secara normatif, skripturalis akan terjebak pada sikap dualistik yakni, di satu sisi norma yang tidak boleh bergeser, di sisi lain realitas umat yang terus berkembang. Misalnya, fenomena tenaga kerja wanita (TKW), norma agama tekstualis menetapkan bahwa perempuan haram bepergian tanpa muhrim. Pencari nafkah adalah kewajiban suami secara mutlak, tapi realitas sekarang istri sebagai pencari nafkah utama jumlahnya cukup signifikan. Setiap perzinaan dihukum rajam atau cambuk, bagaimana dengan korban perkosaan?. Norma agama menganjurkan untuk tidak menceritakan kekurangan suami atau istri, bagaimana dengan kekerasan dalam rumah tangga yang jumlahnya semakin meningkat?. Pembagian hak waris laki-laki 2 bagian, perempuan 1 bagian, bagaimana dengan perempuan yang tidak mendapat akses dan partisipasi pendidikan karena pendidikan mengutamakan anak laki-laki sehingga masa depan perempuan kurang terjamin?, dan masih banyak contoh lain yang sejenis itu.

Beda halnya jika penafsiran teks suci mengacu pada pendekatan emansipatoris, maka peristiwa (realitas) menjadi titik tolak untuk direspon oleh agama (teks suci), kemudian dilakukan analog dengan pendekatan historis dan sosiologis dengan mengacu pada tujuan hukum Islam yakni, nilai-nilai universal agama seperti keadilan, kesetaraan, HAM, menjaga lingkungan yang bersifat tetap. Sedangkan pendekatan dan instrumen lain sebagai pendukung penafsiran dapat berubah sesuai dengan masalahnya. Gender akan terakomodasi dengan baik melalui cara seperti ini karena salah satu dari nilai-nilai universal tersebut adalah keadilan dan kesetaraan gender.

Oleh karena itulah dewasa ini beberapa pemikir muslim kontemporer mengkritisi secara tajam paradigma keilmuan Islamic Studies khususnya paradigma keilmuan fiqh. Bagi mereka fiqh dan implikasinya pada pranata sosial terlalu kaku sehingga kurang responsif terhadap tantangan dan tuntutan perkembangan zaman, khususnya yang berkaitan dengan persoalan-persoalan hudud, hak asasi manusia, hukum publik, perempuan, dan pandangan tentang non muslim. Ilmu-ilmu fiqh yang berimplikasi pada tatanan sosial dalam masyarakat muslim belum berani dan selalu menahan diri untuk bersentuhan dan 
dialog langsung dengan ilmu-ilmu baru yang muncul pada abad 18-19, seperti antropologi, sosiologi, budaya, psikologi, filsafat dan seterusnya ${ }^{5}$.

Ketika kedua tradisi pola pikir yakni Islamic studies konvensional dan religious kontemporer, bertemu dan berdialog, maka kerangka teori, metode dan epistemologi yang digunakan mengalami perubahan. Arkoun mempertanyakan hilangnya dimensi historisitas keilmuan fiqh dan tasawuf. Demikian pula teori nasikh-mansukh yang dipahami ulama ushul fiqh selama ini dengan mengajukan tesis bahwa ayat-ayat makiyah yang lebih bermuatan nilai-nilai universal kemanusiaan tidak dapat dihapus begitu saja oleh ayat-ayat madaniyah yang lebih berorentasi pada problem-problem partikular spesifik dipertanyakan oleh Abdullah Ahmed al Naim. Sahrur mempertanyakan akurasi analisis dan kerangka keilmuan Islam klasik jika harus diaplikasikan seluruhnya pada era kontemporer. Sedangkan Hasan Hanafi melalui Turas wa al Tajdid menggelar paradigma pemikiran yang berbasis kesadaran baik internal maupun eksternal untuk membebaskan sosio kultural Islam dari belenggu ketertinggalan, kemandegan, keterasingan dan ketertutupan. Pada gilirannya, hadist-hadist misoginis juga dipertanyakan oleh Fatima Mernisi, Rifaat Hassan, Aminah Wadud Muhsin dengan memakai analisis gender.

Fatima Mernisi (1940), misalnya, guru besar sosiologi pada Universitas Muhammmad V Rabat, Maroko. Dalam berbagai karyanya, ia menafsirkan kembali teksteks klasik Islam dengan perspektif feminis, terutama pada hadist-hadist mesoginis. Menurutnya, sekalipun Islam bermaksud memberikan posisi perempuan setara dengan laki-laki, tetapi jika misoginis yang berasal dari pra Islam masih bercokol, maka kesetaraan sulit terwujud. Ketidaksetaraan laki-laki dan perempuan karena adanya pemisahan antara ruang publik dan domestik yang masih dipertahankan oleh penduduk Mekkah sebagai warisan tradisi pra Islam yang masih kental di kalangan umat Islam yang masih dipertahankan oleh penduduk Mekkah sebagai warisan tradisi pra Islam yang masih kental di kalangan umat Islam tersendiri.

Perempuan menjadi terpinggirkan disebabkan :

1. Kurangnya jumlah perempuan di bidang kajian kitab suci, menyebabkan dominasi laki-laki sangat besar.

${ }^{5}$ Amin Abdullah., Profil Lulusan Berbasis Kompetensi Akademic-Integralistik Perguruan Tinggi Agama Islam Dalam Era Masyarakat Berubah, Makalah disampaikan pada Pertemuan dan Konsultasi Direktur Program Pasca Sarjana Perguruan Tinggi Agama Islam, Hotel Setia Budi, Jakarta, 24-25 November 2002. 
2. Kuatnya hegemoni laki-laki dalam sistem kehidupan sebagai akibat dari kasus pertama, di mana laki-laki menafsirkan dengan mengesampingkan perspektif perempuan.

3. Adanya kontrol terhadap materi sejarah, dimana citra perempuan dipandang rendah. Hal ini juga dikuatkan oleh kebijakan politik dan ekonomi yang dicarikan legitimasi agama.

Menurutnya, yang harus dilakukan adalah menghindari reduksi citra perempuan dalam masyarakat di luar citra dan sejarah yang bias gender. Dan perbaikan kembali pandangan dunia muslim yang terjepit antara konservatif dan fundamentalistik. ${ }^{6}$

Untuk merubah cara pandang masyarakat atau individu terhadap sesuatu yang diyakini benar menurut agama sama sulitnya dengan merubah budaya yang telah mendarah daging di masyarakat. Lebih-lebih agama, setiap orang dengan dalih agama berani mempertaruhkan nyawa jika diyakini itu benar. Karena itu tidak heran jika sosialisasi gender yang menyentuh persoalan agama jika pembahasannya kurang mendalam dan tuntas akan terjadi resistensi yang cukup tinggi.

Pemahaman gender dan agama dapat berubah-ubah tergantung pada kondisi sosial ekonomi, politik dan pemegang otoritas agama yang bersifat lokal, di sinilah kemudian melahirkan kontroversi dalam memahami gender dan agama. Untuk itu perlu dilakukan upaya berkelanjutan melalui kajian-kajian gender dan agama, dikuatkan pula dengan gerakan praktis di masyarakat seperti pendampingan pemberdayaan berbasis gender dan mengatasi korban kekerasan berbasis gender dengan pendekatan agama sebagai sarana untuk meminimalisir hambatan interpretasi agama dalam konstruksi gender di masyarakat.

\section{Peraturan perundang-undangan, kebijakan dan program pembangunan yang masih} bias gender.

Pemerintah secara resmi telah menganut dan secara resmi pula menetapkan atas persamaan antara perempuan dan laki-laki sebagaimana termuat dalam UUD 45 pasal 27. Ketentuan ini sebagai dasar untuk memberikan akses, partisipasi dan kontrol bagi perempuan dan laki-laki dalam bidang ekonomi, sosial dan politik. Dan dengan ini pula Indonesia kemudian meratifikasi sejumlah konvensi Internasional tentang penghapusan diskriminasi dan peningkatan status perempuan. Demikian pula sejumlah perundang-

\footnotetext{
${ }^{6}$ Khudori Soleh, Pemikiran Islam Kontemporer (Yogyakarta : Pustaka Pelajar , 2003) Hal :131-
} 133. 
undangan dan kebijakan di Indonesia telah menjamin terwujudnya kesetaraan gender antara lain:

1. Kepres No. 129/1998 Program Aksi Nasional Hak Asasi Manusia Indonesia (19982001).

2. Inpres No.9/2000 tentang PUG dalam Pembangunan Nasional.

3. Kepres No. 45/1998 Panduan Implementasi dari Penyeleng-garaan Kemajuan Perempuan dalam Pembangunan di Tk. Nasional.

4. GBHN PROPENAS 2000-2004

5. PROPENAS 2000-2004

6. Rencana Pembangunan Jangka Menengah 2004-2009

7. UU No. 23/2004 Penghapusan Kekerasan Terhadap Perempuan dalam Rumah Tangga (PKDRT)

8. Inpres No. 17/1996 Panduan Teknis untuk Implementasi Manajemen Program Kemajuan Perempuan di Tingkat Sub Nasional.

9. Menaker (04/MEN/88) tentang Implementasi Konvensi Penghapusan Diskriminasi terhadap Pekerjaan Perempuan, yang juga mencakup kesetaraan batas usia pensiun, kesetaraan tanggungan medis, penggunaan air susu ibu, peraturan cuti hamil, dan perlindungan kesehatan pekerjaan perempuan.

Namun demikian perundang-undangan dan kebijakan tersebut dalam pelaksanaannya masih belum efektif. Secara ideal Undang-undang diciptakan dengan tujuan agar kehidupan menjadi teratur dan melindungi segenap masyarakat. Untuk dapat mengetahui sistem kerja hukum sebagai proses, terdapat tiga komponen, yaitu:

1. Komponen struktur (Structure of legal system) terdiri dari institusi pembuat undang-undang, institusi pengadilan dengan strukturnya, institusi kejaksaan dengan dengan strukturnya dan badan kepolisian negara yang berfungsi sebagai aparat penegak hukum.

2. Komponen substansi (Substance of legal system) berupa peraturan-peraturan hukum dan keputusan yang dihasilkan pengadilan dan pembentuk undang-undang serta pemerintah.

Komponen kultur (Culture of legal system) terdiri dari seperangkat nilai-nilai dan sikap-sikap yang berkaitan dengan hukum ${ }^{7}$.

${ }^{7}$ L.M. Friedman, Legal System: A Social Science perspective (Russel Foundation, New York: 1997) h. 14-15 
Substansi hukum merupakan materi hukum yang disusun dengan mempertimbangkan berbagai dimensi, seperti budaya, adat istiadat, ajaran agama, ekonomi, politik dan kondisi masyarakat. Namun demikian substansi hukum disusun tidak lepas pula dengan kepentingan siapa yang menyusunnya. Diantara faktor yang mempengaruhi hukum adalah faktor hukumnya sendir, yang dibatasi oleh undang-undang saja. Semakin baik suatu peraturan akan semakin memungkinkan penegakannya. Sebaliknya, semakin tidak baik suatu peraturan hukum akan semakin sukarlah penegakannya. Suatu peraturan hukum yang baik adalah peraturan hukum yang berlaku secara yuridis, sosiologis dan filosofis.

Jika subtansi hukum secara eksplisit maupun implisit menunjukkan bias gender, maka struktur hukum sebagai pelaksana penegakan hukum lebih sulit untuk bersikap setara dan adil gender. Dalam konteks ini lebih parah lagi jika aparat penegak hukum tidak memiliki sensitifitas gender. Kemudian masih dipertanyakan pula apakah budaya hukum telah berperan mendukung terwujudnya penegakan hukum secara konsekwen?. Karena itu tidak heran jika terjadi kasus-kasus ketidakadilan gender, di mana perempuan yang mayoritas menjadi korban menemukan hambatan serius dalam mencari keadilan. Hal ini merupakan bukti riil bahwa penegakan hukum dan budaya hukum yang dibangun oleh masyarakat masih belum mendukung secara maksimal

Undang-undang No 1 Tahun 1974 tentang Perkawinan, sebagian masih mencerminkan bias gender, misalnya suami sebagai kepala keluarga dan pencari nafkah, sedangkan istri sebagai ibu rumah tangga. Pembagian kerja dan status yang rigid ini sudah tidak dapat dipertahankan lagi, karena istri yang menghidupi dirinya dan keluarganya jumlahnya di Indonesia cukup signifikan. Pembagian inipun tidak menguntungkan kedua belah fihak. Pemaksaan semua suami sebagai pemimpin keluarga dan pencari nafkah utama tanpa memperhatikan kualifikasi yang berbeda-beda, sedangkan istri yang menjadi single parent, sering dipandang masyarakat tidak berkepala keluarga, akses dan partisipasinya dalam kehidupan tidak sebagaimana suami yang secara eksplisit disebutkan dalam undang-undang. Dalam UU Perkawinan khususnya yang menyangkut aturan poligami berdampak pada kekerasan terhadap perempuan.

Sejumlah UU yang masih diskriminatif terhadap perempuan, antara lain: UU tentang Kewarganegaraan Nomor 62 tahun 1958, pemerintah menetapkan apa yang disebut dengan doktrin kesatuan hukum (One person in the law doctrine), di mana suami atau bapak menjadi rujukan utama yang digunakan untuk menentukan kewarganegaraan anakanaknya. Demikian pula tentang sistem pengupahan tenaga kerja perempuan, tunjangan 
keluarga dan tunjangan kesehatan-perempuan dianggap lajang sehingga suami dan anakanak tidak mendapatkan tunjangan sebagaimana yang diterima pekerja laki-laki. Ketentuan ini termuat dalam Surat Edaran Menteri Tenaga Kerja No. 7 tahun 1990 tentang Upah, PP No. 37 tahun 1967 tentang Sistem Pengupahan di lingkungan perusahaan negara, Peraturan Menteri Pertambangan No.2/P/M/1971, Peraturan Menteri Pertanian No.K440/01/2/1984 dan No.01/GKKU/3/1978 dan SE Menaker No.4/1988 tentang tunjangan kesehatan, serta pasal 8 UU No.7/1983, pasal 4 Perturan Menteri Keuangan No. 947/KMK/04/1983 dan pasal 8 UUNo. 10/1994 tentang prosedur memperoleh NPWP. Kondisi Peraturan perundang-undangan tidak mampu mengkomodir kepentingan perempuan dan laki-laki secara setara sebagaimana telah dijamin oleh UUD, karena akses dan partisipasi perempuan dalam penyusunan undang-undang sejak berdirinya negara ini sangat rendah, sehingga undang-undang tidak berfihak pada kesetaraan dan keadilan gender.

Perjuangan aktifis perempuan di Indonesia telah membuahkan hasil sekalipun belum maksimal, yaitu UU Perlindungan Anak No. 23 tahun 2002 dan UU No.23 tahun 2004 tentang Penghapusan Kekerasan Dalam Rumah Tangga (PKDRT). Masih diperlukan Undang-undang Penghapusan Perdagangan Perempuan dan Anak, Undang-undang Perlindungan Korban dan Saksi yang terus diperjuangkan. Masih menjadi catatan penting bahwa implementsi UU Perlindungan Anak dan UU PKDRT masih mengalami kendala. Permasalahannya adalah political will dari pihak penegak hukum masih belum sepenuhnya responsif gender.

Untuk konteks pembangunan, isu perempuan dan pembangunan menjadi sangat penting karena selama ini perempuan pada umumnya termarjinalkan dalam proses pembangunan dikarenakan secara absolut negara salah menempatkan perempuan perempuan pada peran tradisional begitu juga aktifitas-aktifitas yang dilakukan perempuan. Selain itu, negara juga secara relatif tidak diperhitungkan dalam usaha-usaha pembangunan tidak menikmati hasil-hasilnya sebagaimana yang didapat oleh laki-laki. ${ }^{8}$

Untuk program pembangunan di Indonesia saat ini sedang berlangsung adalah menggunakan strategi PUG menyusul pergeseran paradigma Women in Development (WID) dan Women and Development (WAD) menuju Gender and Development (GAD). Perubahan paradigma ini diikuti oleh dikeluarkannya Instruksi Presiden No. 9 Tahun 2000 tentang Pengarusutamaan Gender dalam program pembangunan nasional sampai daerah, namun setiap strategi disamping memiliki kelebihan, juga memiliki kekurangan. Kebijakan pemerintah untuk menggunakan acuan Pengarusutamaan Gender (PUG) dalam program

\footnotetext{
${ }^{8}$ Antrobus, The Global........., hal. 47
} 
pembangunan sejak Inpres ini dikeluarkan di tingkat implementasinya masih dipertanyakan. Evaluasi yang dilakukan oleh Kementerian Pemberdayaan Perempuan tentang pelaksanaan PUG di berbagai kebijakan pemerintah di tingkat nasional maupun daerah belum menunjukan hasil sesuai dengan harapan. Kendala yang dihadapi justru berbentuk kendala struktural di mana political will dari pemerintah sendiri tidak responsif gender dan ditunjang pula oleh aparat yang belum sensitif gender.

\section{G. Penutup}

Hingga saat ini masalah ketidakadilan gender masih menjadi pembahasan menarik di kalangan akademik, dan masih dalam proses perjuangan panjang bagi aktifis gender. Sekalipun negara melalui UUD 45 telah menjamin akses perempuan dan laki-laki secara setara, namun dalam implementasinya masih mengalami banyak hambatan. Budaya patriarkhi yang sebagian besar dianut oleh masyarakat Indonesia turut melanggengkan ketimpangan gender tersebut. Pemahaman agama yang tidak sesuai dengan pesan-pesan ideal moral agama berdampak pada penafsiran ahistoris, normatif, skripturalis, yang menyebabkan hilangnya ruh dan semangat beragama secara dinamis dan emansipatoris. Padahal agama adalah sebagai pembawa kedamaian dan keadilan, tak terkecuali keadilan gender. Peraturan perundang-undangan yang ada masih belum sepenuhnya ramah gender. Berbagai isu ketimpangan gender di masyarakat masih belum ada upaya signifikan dari semua komponen masyarakat, seperti kekerasan terhadap perempuan, perdagangan perempuan dan anak, pornografi ketenagakerjaan perempuan seperti masalah buruh migran dan TKW di luar negeri, rendahnya partisipasi perempuan bidang politik, bidang pendidikan terutama pada level SMA dan perguruan tinggi. Masih buruknya kondisi kesehatan reproduksi terutama pada keluarga miskin. Untuk itu terus menerus dilakukan upaya menghapus kendala terjadinya diskriminasi gender dan pengembangan potensi yang dapat mendukung kesetaraan dan keadilan gender. 


\section{DAFTAR PUSTAKA}

Abdullah, Amin, 2002, Profil Lulusan Berbasis Kompetensi Akademic-Integralistik Perguruan Tinggi Agama Islam Dalam Era Masyarakat Berubah, Makalah disampaikan pada Pertemuan dan Konsultasi Direktur Program Pasca Sarjana Perguruan Tinggi Agama Islam, Hotel Setia Budi, Jakarta, 24-25 November 2002.

Antrobus, Peggy, 2004, The Global Women's Movement, Bangladesh: The University Press,

Dzuhayatin, Siti Ruhaini, 2001, Pengantar dalam Gender dan Rekonstruksi Methodologis Studi-studi Islam (Yogyakarta: PSW IAIN Sunan Kalijaga).

Faqih, Mansour, 1997 Gender dan Transformasi Social,Yogyakarta: Pustaka Pelajar.

Friedman, L.M., 1997, Legal System: A Social Science perspective New York: Russel Foundation.

Irwan, 1999, Perisai Perempuan: Kesepakatan Internasional Untuk Perlindungan Perempuan Jakarta: LBH APIK, Forum Komunikasi LSM Perempuan \& Ford Foundation.

Kementerian Pemberdayaan Perempuan, 2002, Pemberdayaan Perempuan dalam Pembangunan Nasional : Jakarta.

Mernissi, Fatima, 1991, Wanita dalam Islam, terjemah: Raziar Radianti, Bandung: Pustaka Britama. dan Riffat Hassan,1995, Setara dihadapan Allah, Relasi Laki-laki dan Perempuan dalam Tradisi Islam Pasca Patriarkhi, Terjemah Tim LSPPA, Yogyakarta: LSPPA-Yayasan Prakarsa.

Mufidah Ch, 2004, Paradigma Gender, Malang: Bayu Media.

Rahman, Fazlur, 1985, Islam dan Modernisme: Teks transformasi Intelektual, terjemah: Ahsin Muhammad, Bandung: Pustaka.

Soleh, Khudori, 2002 , Pemikiran Islam Kontemporer, Yogyakarta : Pustaka Pelajar.

Umar, Nasaruddin, 1999, Argumen Kesetaraan Gender, Jakarta: PARAMADINA. , 2004, Isu-isu ketidakadilan Gender dalam Islam, Makalah disampaikan dalam Workshop Sensitivitas Gender bagi guru madrasah Aliyah seDI Yogyakarta, Pusat Studi Wanita, UIN Yogyakarta, 27 Agustus 2004. 